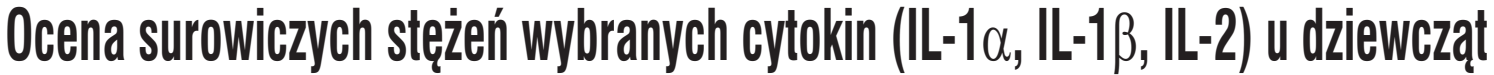 z jadlowstręetem psychicznym i otylością prostą
}

\section{Assessment of some serum circulating cytokines concentrations (IL-1 $\alpha$, IL-1 $\beta$, IL-2) in girls with anorexia nervosa and simple obesity}

\author{
${ }^{1}$ Katarzyna Ziora, ${ }^{2}$ Marta Świder, ${ }^{3}$ Bogdan Mazur, ${ }^{1}$ Joanna Oświęcimska, ${ }^{1}$ Magdalena Jachimowicz, \\ ${ }^{4}$ Paweł Matusik, ${ }^{4}$ Ewa Małecka-Tendera

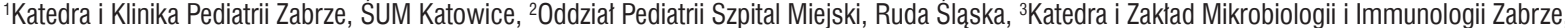
ŚUM Katowice, ${ }^{4}$ Katedra i Klinika Pediatrii, Endokrynologii i Diabetologii, ŚUM Katowice

${ }^{1}$ Chair and Department of Paediatrics, Zabrze, Medical University of Silesia, Katowice, ${ }^{2}$ Department of Paediatrics, Local Hospital Ruda Ślaska, ${ }^{3}$ Chair and Department of Microbiology and Immunology Zabrze, Medical University of Silesia, Katowice, ${ }^{4}$ Chair and Department of Paediatric
\end{abstract} \\ Endocrinology and Diabetes Katowice, Medical University of Silesia, Katowice
}

\author{
Adres do korespondencji: $\quad$ Katarzyna Ziora, SP Szpital Kliniczny nr 1, ul. 3 Maja 13/15 41-800 Zabrze, tel.: 323704 284; ziorkasia@wp.pl \\ Słowa kluczowe: cytokiny, IL-1, IL-2, jadłowstręt psychiczny, otyłość \\ Key words: cytokines, IL-1, IL-2, anorexia nervosa, obesity
}

Badanie wykonano w oparciu o grant: KNW-1-051/D/1/0 i KNW-1-089/P/1/0

\section{ABSTRACT/STRESZCZENIE}

Ekspresję IL-1 stwierdza się w komórkach podścieliska tkanki tłuszczowej, a IL-2 w adipocytach. Nadprodukcja IL-1 może prowadzić do zespołu anorexia-cachexia. Brakuje doniesień na temat porównania stężeń krążących we krwi cytokin w grupie osób z dużą rozpiętością masy ciała - od niedożywienia do otyłości. Cel pracy. Ocena profilu stężeń IL-1 $\alpha$, IL-1 $\beta$, IL-2 we krwi u dziewcząt z anorexia nervosa (AN) w porównaniu do otyłych (OT) i zdrowych (ZD) oraz analiza zależności pomiędzy stężeniem tych cytokin a masą ciała, BMI i stężeniem insuliny. Material i metody. U 80 dziewcząt (wiek 13-18 lat): 30 z AN (śr. BMI: 14,94 $\pm 0,63$ kg/m²; śr. BMI-SDS: -2,93 $\pm 0,41$ ), 30 z OT (śr. BMI: $30,59 \pm 1,41 \mathrm{~kg} / \mathrm{m}^{2}$; śr. BMI-SDS: 6,41 \pm 0,8) i 20 ZD (śr. BMI: 20,83 $\pm 1,07 \mathrm{~kg} / \mathrm{m}^{2}$; śr. BMI-SDS: 0,17 \pm 0,54) oznaczono stężenia IL-1 $\alpha$, IL-1 $\beta$ i IL-2 w surowicy metodą ELISA, a insuliny (INS) metodą IRMA. Wyniki. Średnie stężenie IL- $1 \alpha(13,15 \pm 3,8 \mathrm{pg} / \mathrm{ml})$ i IL-1 $\beta(2,63 \pm 0,9 \mathrm{pg} / \mathrm{ml})$ w surowicy w grupie AN było istotnie wyższe niż w grupie OT $(4,72 \pm 1,4 \mathrm{pg} / \mathrm{ml}$ i $1,33 \pm 0,6 \mathrm{pg} / \mathrm{ml}$ odpowiednio; $\mathrm{p}<0,05)$ i ZD $(6,78 \pm 1,5 \mathrm{pg} / \mathrm{ml}$ i $1,09 \pm 0,6 \mathrm{pg} / \mathrm{ml}$ odpowiednio; $\mathrm{p}<0,05)$. Najniższe średnie stężenia IL-2 $\mathrm{w}$ surowicy obserwowano $\mathrm{w}$ grupie AN $(3,76 \pm 0,7 \mathrm{pg} / \mathrm{ml})$, następnie u OT $(10,66 \pm 3,5 \mathrm{pg} / \mathrm{ml})$ i ZD $(18,07 \pm 4,2 \mathrm{pg} / \mathrm{ml})(\mathrm{p}<0,05)$. Wykazano korelację ujemną pomiędzy stężeniem IL-1 $\alpha$ i IL-1 $\beta$ i dodatnią pomiędzy stężeniem IL-2 a BMI i INS we krwi u wszystkich badanych $(p<0,05)$. Wnioski. 1. Wyższe stężenia IL-1 $\alpha$ i IL-1 $\beta$ we krwi w AN aniżeli u OT i ZD mogą wpływać na zahamowanie poboru 
pokarmu u tych chorych. 2. Niższe stężenia IL-2 we krwi u AN aniżeli u OT i ZD mogą wynikać z „depresji” układu immunologicznego. 3. Dodatnia zależność pomiędzy stężeniem IL-2 cytokiny we krwi a stopniem odżywienia może świadczyć o tym, że przyczyną dysregulacji immunologicznej w zakresie tej cytokiny może być niedożywienie. 4. Ujemna korelacja pomiędzy stężeniem IL-1 $\alpha$ i IL-1 $\beta$, a dodatnia pomiędzy IL-2 a stężeniem INS we krwi w całej badanej grupie, gdzie obserwuje się duży rozrzut wartości masy ciała, może wskazywać, że cytokiny te odgrywają rolę w modelowaniu insulinooporności zależnie od masy ciała. Endokrynol. Ped. 12/2013;3(44):17-30.

Expression of IL-1 is found in fat tissue stroma and IL-2 in adipocytes. Overproduction of IL-1 may cause anorexiacachexia syndrome. There are no reports comparing the circulating cytokines concentrations in a group of subjects with wide range of body weight - from undernutrition to obesity. The aim of the study was the assessment of IL-1 $\alpha$, IL-1 $\beta$ and IL-2 blood concentrations in girls with anorexia nervosa (AN), simple obesity (OB) and healthy controls (H) and analysis of their correlations with body weight, BMI and insulin concentration. Material and methods. In 80 girls (aged 13-18 years): 30 with AN (mean BMI: 14,94 $\pm 0,63 \mathrm{~kg} / \mathrm{m}^{2}$; mean BMI-SDS: $-2,93 \pm 0,41$ ), 30 with OB (mean BMI: 30,59 $\pm 1,41 \mathrm{~kg} / \mathrm{m}^{2}$; mean BMI-SDS: 6,41 \pm 0,8) and $20 \mathrm{H}$ (mean BMI: 20,83 $\pm 1,07 \mathrm{~kg} / \mathrm{m}^{2}$; mean BMI-SDS: $0,17 \pm 0,54)$ serum IL-1 $\alpha$, IL-1 $\beta$, IL-2 (ELISA) and insulin (INS; IRMA) concentrations were established. Results. Mean serum IL- $\alpha(13,15 \pm 3,8 \mathrm{pg} / \mathrm{ml})$ and IL- $1 \beta(2,63 \pm 0,9 \mathrm{pg} / \mathrm{ml})$ were significantly higher in AN than in $\mathrm{OB}(4,72 \pm 1,4 \mathrm{pg} / \mathrm{ml}$ and1,33 $\pm 0,6 \mathrm{pg} / \mathrm{ml}$, respectively; $\mathrm{p}<0,05)$ and $\mathrm{H}(6,78 \pm 1,5 \mathrm{pg} / \mathrm{ml}$ and $1,09 \pm 0,6 \mathrm{pg} / \mathrm{ml}$, respectively; $\mathrm{p}<0,05)$. The lowest serum IL-2 concentrations were found in AN as compared to $\mathrm{OB}$ or $\mathrm{H}(3,76 \pm$ $0,7 \mathrm{pg} / \mathrm{ml}$ vs $10,66 \pm 3,5 \mathrm{pg} / \mathrm{ml}$ vs $18,07 \pm 4,2 \mathrm{pg} / \mathrm{ml}$ respectively, $\mathrm{p}<0,05)$. The significant negative correlations between serum IL- $1 \alpha$ and IL- $1 \beta$ and positive one between serum IL-2 and BMI or INS in all examined subjects were noted $(\mathrm{p}<0,05)$. Conclusions. 1. Increased IL-1 $\alpha$ and IL-1 $\beta$ concentrations in AN girls may affect reduced food intake in these patients. 2. Lower than in OB and H IL-2 concentrations in AN girls may result from immune system depression. 3. Positive correlation between serum Il-2 and nutritional status may suggest that disturbed production of this cytokine is caused by undernutrition. 4 . Negative correlations of IL-1 $\alpha$ and IL-1 $\beta$ and positive one of IL-2 with INS concentrations, observed in all examined subjects with wide body mass range, suggest that those cytokines may play a role in development of insulin resistance dependent on body mass. Pediatr. Endocrinol. 12/2013;3(44):17-30

\section{Wstęp}

U podłoża zaburzeń odżywiania mogą leżeć zmiany w produkcji i wydzielaniu cytokin. Nadmierna synteza jednych lub zbyt mała innych może odgrywać rolę $\mathrm{w}$ patogenezie jadłowstrętu psychicznego [1].

Cytokiny są produkowane nie tylko przez makrofagi, monocyty, limfocyty, ale także przez keratynocyty, fibroblasty, granulocyty, eozynofile, chondrocyty, osteoblasty, komórki błony śluzowej jelit i OUN oraz adipocyty. Interleukina-1 jest syntetyzowana przez makrofagi i fibroblasty wchodzące w skład podścieliska tkanki tłuszczowej. W komórkach i podścielisku tkanki tłuszczowej wykazano także ekspresję innych cytokin, m.in. interleukiny-2 $[2,3]$.

Interleukina -1 (IL-1) opisana jako białko indukujące gorączkę została nazwana pierwotnie human leukocytic pirogen. Była to pierwsza poznana cytokina wytwarzana przez keratynocyty, stąd jej inna nazwa: naskórkopochodny czynnik aktywujący tymocyty (epidermal cell-derived thymocyte activating factor, ETAF). Nazwy IL-1 używa się głównie dla dwóch podklas: IL-1 $\alpha$ i IL-1 $\beta$, które są heterodimerami o masie cząsteczkowej $17 \mathrm{kDa}$ [3].
Chociaż IL-1 $\alpha$ i IL-1 $\beta$ zaledwie w $25 \%$ mają homologiczną sekwencję, różną lokalizację, dojrzewanie i sekrecję, to jednak wykazują podobne właściwości biologiczne [3]. IL-1 $\alpha$ działa jako cząsteczka błonowa tylko na komórki położone najbliżej. Może działać też jako prekursor, podczas gdy IL-1 $\beta$ nie posiada aktywności biologicznej aż do momentu, gdy zostanie poddana procesowi uaktywnienia przez proteazę cysteinową (interleukin $1 \beta$ converting enzyme, ICE) zwaną kaspazą-1. IL$1 \alpha$ i IL-1 $\beta$ wywierają podobne efekty po związaniu $\mathrm{z}$ receptorem IL-1 typu I (IL-1RI). Mogą też wiązać się z receptorem IL-1 typu II (IL-1RII), który działa jak receptor ,pułapka”, nie wywołując transdukcji sygnału $[3,4]$.

IL-1 jest cytokiną potencjalnie prozapalną. Pośredniczy w stanach zapalnych poprzez inicjowanie i potęgowanie odpowiedzi immunologicznej i zapalnej. Bierze udział w proliferacji i różnicowaniu komórek. Ma wpływ na funkcje komórek wrodzonych, specyficznie immunokompetentnych [3].

IL-1 stymuluje komórki do syntezy IL-2, pobudza wczesne etapy dojrzewania tymocytów, wpływa na proliferację limfocytów $T$, pobudza wytwarzanie IL-6 przez makrofagi, komórki śródbłonka i fibroblasty, pobudza syntezę interferonu- $\gamma$ przez 
limfocyty $\mathrm{T}$, proliferację limfocytów B, wzrost syntezy przeciwciał, uwalnianie G-CSF i GM-CSF, co powoduje wzrost wytwarzania neutrofilów i monocytów. Pobudza do wydzielania czynnika aktywacji płytek (PAF) i płytkopochodnego czynnika wzrostu (PDGF), co prowadzi do wzrostu proliferacji fibroblastów i miocytów. Stymuluje uwalnianie histaminy przez bazofile, degranulację eozynofili, wzrost syntezy tlenku azotu. Ponadto odgrywa rolę we wzroście syntezy białek ostrej fazy w wątrobie, uczestniczy w procesach resorpcji i przebudowy kości, wpływa na katabolizm komórek mięśniowych $[4,5]$.

Znany jest też wpływ IL-1 na OUN. Powoduje wzrost temperatury ciała, senność i jadłowstręt. Wpływając na zwiększenie wytwarzania $\mathrm{CRH}$ w podwzgórzu i wydzielania ACTH w przysadce, odgrywa rolę $\mathrm{w}$ uruchamianiu naturalnego procesu immunosupresji, głównie w ochronie przed nadmierną, niekontrolowaną reakcją zapalną [4].

Obserwacje poczynione $\mathrm{u}$ chorych z AIDS wskazują, że IL-1 jest zaangażowana w regulację poboru pokarmu i rozwój zespołu anorexia-cachexia [6].

Uważa się, że IL-1 $\beta$ może modulować insulinowrażliwość $[4,5,7]$.

Interleukina-2 (IL-2) zwana czynnikiem wzrostowym limfocytów to monomer o masie cząsteczkowej $15,5 \mathrm{kDa}$. Działa poprzez swoisty receptor (IL-2R), złożony z trzech podjednostek: łańcucha $\alpha$ (IL-2R $\alpha$ ), $\beta$ (IL-2R $\beta$ ) i łańcucha $\gamma$. IL-2R $\alpha$ i IL-2R $\beta$ odpowiadają za wiązanie receptora $\mathrm{z}$ cytokiną, podczas gdy IL-2R $\beta$ wraz z podjednostką $\gamma c$ są włączone $w$ transdukcję sygnału $[3,4]$.

IL-2 jest uwalniana głównie przez aktywowane limfocyty T CD4+ i CD8+, rozpoznające antygen przez TCR, głównie Th1 i w mniejszym stopniu przez Tc. Jest też uwalniana przez aktywowane komórki dendrytyczne, NK i NK T, lecz znaczenie biologiczne tego faktu nie jest jeszcze znane [3]. Innymi źródłami IL-2 są też błona śluzowa jelit, komórki OUN i komórki tkanki thuszczowej [6], a więc tkanki włączone w regulację poboru pokarmu.

IL-2 jest czynnikiem wzrostu dla limfocytów T pomocniczych, komórek NK i limfocytów T regulatorowych i supresorowych. Wspomaga wytwarzanie innych cytokin, takich jak IFN- $\gamma$, IL-6, GM- CSF, limfotoksyn i samej siebie. Wpływa na proliferację i różnicowanie limfocytów B w kooperacji z IL-4 i IL-5, na pobudzenie proliferacji limfocytów T cytotoksycznych CD 8+ szczególnie tych, które niedawno rozpoznały antygen oraz różnicowanie lim- focytów T w kierunku cytotoksycznych. Odgrywa istotną rolę w ochronie przed autoimmunizacją [4].

IL-2 jest jednym $\mathrm{z}$ kluczowych mediatorów w chorobach autoimmunizacyjnych, a jej zwiększone stężenie we krwi chroni przed autoagresją. IL-2 jest jedną z najważniejszych cytokin uczestniczących w wygaszaniu reakcji immunologicznej po wyeliminowaniu antygenu [4]. Rekombinowana IL-2 jest wykorzystywana $\mathrm{w}$ immunoterapii raków i AIDS [3, 4].

$\mathrm{U}$ pacjentów $\mathrm{z}$ jadłowstrętem psychicznym (anorexia nervosa, AN) prowadzono już wcześniej badania doświadczalne dotyczące IL-1 i IL-2 w kulturach hodowli leukocytów in vitro [8-11]. Były też badania kliniczne oceniające stężenia tych cytokin we krwi lub innych płynach ustrojowych, a także ich ekspresję w tkance tłuszczowej $[6,12,13]$. Jednak wyniki tych badań są rozbieżne. Większość prac dotyczy kobiet dorosłych, jedynie pojedyncze prace odnoszą się do dziewcząt z AN [14-17]. Na ogół autorzy porównują grupę chorych z AN do grupy zdrowych. Są tylko nieliczne prace, w których autorzy porównują wyniki uzyskane $\mathrm{u}$ pacjentów z AN do wyników badań u otyłych [18].

W przebiegu AN dochodzi do znacznego niedoboru masy ciała i spadku BMI poniżej normy. W cytowanych pracach u chorych z AN brakuje odniesienia stężeń badanych cytokin we krwi do masy ciała i innych parametrów stanu odżywienia, jak wskaźnik Cole’a czy BMI.

\section{Cel pracy}

1. Ocena stężeń IL-1 $\alpha$, IL-1 $\beta$ oraz IL-2 w surowicy krwi u dziewcząt $\mathrm{z}$ jadłowstrętem psychicznym $w$ porównaniu do dziewcząt $\mathrm{z}$ otyłością prostą i zdrowych.

2. Analiza zależności pomiędzy stężeniem wymienionych cytokin we krwi a masą ciała i BMI w grupie $\mathrm{z}$ jadłowstrętem psychicznym i w całej badanej grupie.

3. Analiza korelacji pomiędzy stężeniem IL-1 $\alpha$, IL-1 $\beta$ i IL-2 a stężeniem insuliny we krwi u dziewcząt $\mathrm{z}$ jadłowstrętem psychicznym i w całej badanej grupie.

\section{Materiał i metodyka}

Badania przeprowadzono u 80 dziewcząt, w tym 30 dziewcząt $\mathrm{z}$ anorexia nervosa typu restrykcyjnego (wg klasyfikacji DSM-IV) [19] (AN), leczonych w SP Szpitalu Klinicznym Nr 1 w Zabrzu, 
30 dziewcząt z otyłością prostą (OT), rekrutowanych z Poradni Endokrynologicznych w Górnośląskim Centrum Pediatrii w Katowicach i SP SK Nr 1 w Zabrzu oraz 20 dziewcząt zdrowych (ZD), uczennic szkół w Zabrzu, które wyraziły chęć uczestniczenia w badaniach.

W grupie AN badania wykonano w pierwszych trzech dniach hospitalizacji, przed rozpoczęciem terapii. U każdej z pacjentek wykluczono inne niż AN schorzenia somatyczne i psychiczne mogące być przyczyną wyniszczenia.

Średni wiek badanych w grupie AN wynosił $15,7 \pm 0,5$ lat (tab. I). U wszystkich stwierdzano pierwotny lub wtórny brak miesiączki. Średni czas trwania choroby, tj. intensywnego odchudzania się, do momentu zgłoszenia się do szpitala wynosił 18,5 $\pm 5,91$ miesiąca (3- 60 miesięcy).

Średnia masa ciała chorych w grupie AN wynosiła $38,7 \pm 1,3 \mathrm{~kg}$ (tab. I). U każdej badanej wyliczono wskaźnik masy ciała $\mathrm{BMI}=[\mathrm{m}$. ciała $(\mathrm{kg})] /$ wzrost $(\mathrm{m})^{2}$ oraz odchylenie standardowe dla BMI: BMI-SDS (standard deviation score). Do oceny BMI-SDS posłużono się siatkami centylowymi BMI, opracowanymi przez Palczewską i wsp. dla płci i wieku, obowiązującymi w populacji polskiej [20]. Średni wskaźnik BMI wynosił w tej grupie $14,9 \pm 0,6 \mathrm{~kg} / \mathrm{m}^{2}$, a średnie BMI-SDS wynosiło $-2,93 \pm 0,4$ (tab. I). Obliczono także wskaźnik
Cole'a, który odzwierciedla stopień odżywienia. Kwalifikacja wskaźnika Cole'a obejmuje następujące zakresy: $<75 \%$ : wyniszczenie, $75-85 \%$ : niedożywienie; 85-90\% : nieznaczne niedożywienie; 90-100\%: norma; > 110\%: nadmierne odżywienie [21]. Średni wskaźnik Cole' a u dziewcząt z AN wynosił $76 \pm 0,04 \%$ (tab. I).

Do grupy OT zakwalifikowano dziewczęta, których BMI wykraczało poza 97 centyl oceniony na podstawie siatek centylowych, a BMI-SDS było większe niż 2 odchylenia standardowe. Średni wiek dziewcząt z OT wynosił 14,7 $\pm 0,9$ lat (tab. I). Żadna $z$ badanych $w$ grupie OT nie chorowała na choroby przewlekłe i nie stosowała leków na stałe ani na co najmniej miesiąc przed planowanym badaniem. Żadna nie stosowała diet lub innych sposobów odchudzania w ciągu ostatnich trzech miesięcy przed badaniem. Średnia masa ciała w grupie OT wynosiła $78,9 \pm 6,2 \mathrm{~kg}$, BMI: $30,6 \pm 1,4 \mathrm{~kg} / \mathrm{m}^{2}$, BMI-SDS: $6,4 \pm 0,8$, a wskaźnik Cole'a: $165 \pm 0,1 \%$ (tab. I).

Wiek dziewcząt $w$ grupie ZD wynosił średnio $15,1 \pm 0,3$ lat, masa ciała: $58,3 \pm 4,1 \mathrm{~kg}$, BMI: $20,8 \pm 1,1 \mathrm{~kg} / \mathrm{m}^{2}$, BMI-SDS: $0,17 \pm 0,5$, a wskaźnik Cole'a: $104 \pm 0,1 \%$ (tab. I). W dniu badania żadna $\mathrm{z}$ dziewcząt nie zgłaszała dolegliwości, nie miała ostrej infekcji w ciągu ostatniego miesiąca przed badaniem.

Tabela I. Charakterystyka badanych grup dziewcząt; AN - grupa badanych z anorexia nervosa, OT - grupa dziewcząt z otyłością prostą, ZD - grupa dziewcząt zdrowych

Table I. Characteristics of examined groups of girls; AN - group with anorexia nervosa, OT - group with simple obesity, ZD - healthy group

\begin{tabular}{|c|c|c|c|}
\hline \multirow{2}{*}{ Wiek (lata) } & AN $(\mathrm{n}=30)$ & OT $(\mathrm{n}=30)$ & ZD $(\mathrm{n}=20)$ \\
\cline { 2 - 4 } & $\begin{array}{c}\text { średnia } \pm 1,96 \text { SE } \\
\text { (zakres) }\end{array}$ & $\begin{array}{c}\text { średnia } \pm 1,96 \text { SE } \\
\text { (zakres) }\end{array}$ & $\begin{array}{c}\text { średnia } \pm 1,96 \text { SE } \\
\text { (zakres) }\end{array}$ \\
\hline \multirow{2}{*}{ Masa ciała (kg) } & $15,66 \pm 0,52$ & $14,73 \pm 0,85$ & $15,10 \pm 0,3$ \\
& $(13,0-17,92)$ & $(13,0-17,67)$ & $(13,08-18,42)$ \\
Wzrost (cm) & $38,70^{*} \pm 1,31$ & $78,94 \pm 6,15$ & $58,29 \pm 4,13$ \\
& $(28,8-47,6)$ & $(48,0-107,0)$ & $(45,8-75,0)$ \\
BMI (kg/m2) & $161,02 \pm 1,96$ & $159,66 \pm 3,52$ & $167,1 \pm 3,37$ \\
& $(150,0-69,1)$ & $(138,0-175,0)$ & $(150,0-179,0)$ \\
BMI-SDS & $14,94 * \pm 0,63$ & $30,59 \pm 1,41$ & $20,83 \pm 1,07$ \\
& $(11,38-18,5)$ & $(24,6-38,2)$ & $(16,95-24,88)$ \\
Wskaźnik Cole'a (\%) & $-2,93 * \pm 0,41$ & $6,41 \pm 0,8$ & $0,17 \pm 0,54$ \\
& $(-5,23-0,9)$ & $(2,60-10,49)$ & $(-1,97-2,0)$ \\
\hline
\end{tabular}

${ }^{*} p<0,001$ AN vs ZD i OT 
Badanie przeprowadzono między godz. 7.00 a 8.00 rano, na czczo po 12-godzinnym poszczeniu. Krew odwirowywano, a uzyskaną surowicę przechowywano w temperaturze $-70^{\circ} \mathrm{C}$.

$\mathrm{Na}$ przeprowadzenie badań uzyskano zgodę Komisji Bioetycznej Śląskiego Uniwersytetu Medycznego (Uchwała $\mathrm{nr}$ KNW/0022/KBI/2/I/11 $\mathrm{z}$ dn.15.03.2011) oraz zgodę pacjentek i ich rodziców lub opiekunów prawnych.

Oznaczanie surowiczych stężeń IL-1 $\alpha$, IL-1 $\beta$ i IL-2 wykonano metodą High Sensitivity Human ELISA kit (Enzyme Linked Immunoabsorbent Assay), przy użyciu zestawów firmy Abcam zgodnie $\mathrm{z}$ metodami podanymi przez producenta. Pomiaru absorpcji dokonywano za pomocą automatycznego czytnika Elx800 firmy BIO-TEK Instruments (USA) przy długości fali zalecanej przez producenta.

Oznaczenie stężenia insuliny (INS) i wysoko czułego białka CRP (hsCRP) określano przy pomocy analizatora biochemicznego Cobas 6000 firmy Roche (USA). Wszystkie oznaczenia przeprowadzono w Laboratorium Centralnym SP Szpitala Klinicznego Nr 1 w Zabrzu.

\section{Analiza statystyczna}

Do obliczeń statystycznych wykorzystano program Statistica v. 4.3 En. Przyjęto poziom istotności $\alpha=0,05$. Dla wszystkich parametrów sprawdzono zgodność ich rozkładów z rozkładem normalnym. W ocenie zgodności posłużono się testem Shapiro-Wilka oraz histogramami zmiennych z naniesioną krzywą Gausa. Homogeniczność wariancji sprawdzono testem Levene'a. Dla zmiennych o rozkładzie normalnym stosowano testy parametryczne $t \mathrm{z}$ oddzielną oceną wariancji. Przeprowadzono analizę wariancji wieloczynikowej ANOVA. Dla zmiennych, których rozkład odbiegał od rozkładu normalnego zastosowano testy nieparametryczne U Manna-Whitneya, ANOVA, Rang Kruskala-Wallisa, mediany, oraz test dla porównań wielokrotnych. Obliczono współczynniki korelacji Rang Spearmana.

\section{Wyniki}

Średni wiek dziewcząt w grupie anorexia nervosa był podobny do średniego wieku dziewcząt w grupach kontrolnych (tab. I). W grupie AN średnia masa ciała, BMI, BMI-SDS oraz wskaźnik Cole’a były znamiennie niższe aniżeli $\mathrm{w}$ grupach OT i ZD $(\mathrm{p}<0,001)$ (tab. I).

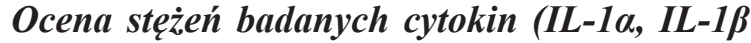
i IL-2) w surowicy krwi u dziewcząt $z$ jadtowstrętem psychicznym w porównaniu do dziewcząt otylych $i$ zdrowych

Wartości średnich stężeń badanych cytokin oraz INS i hCRP $\mathrm{w}$ surowicy krwi zamieszczono $\mathrm{w}$ tabeli II.

Średnie stężenie IL-1 $\alpha \mathrm{w}$ surowicy krwi w grupie z anorexia nervosa wynosiło $13,15 \pm 3,8 \mathrm{pg} / \mathrm{ml}$ $\mathrm{i}$ było istotnie wyższe $(\mathrm{p}<0,001)$ aniżeli $\mathrm{w}$ grupie otyłych $(4,72 \pm 1,4 \mathrm{pg} / \mathrm{ml})$ i zdrowych dziewcząt $(6,78 \pm 1,5 \mathrm{pg} / \mathrm{ml})(\mathrm{p}<0,05)$ (tab. II, ryc.1).

Średnie stężenie IL-1 $\beta$ w surowicy krwi u dziewcząt w grupie AN wynosiło $2,63 \pm 0,9 \mathrm{pg} / \mathrm{ml}$ i było istotnie wyższe niż w grupie OT $(1,33 \pm 0,63 \mathrm{pg} / \mathrm{ml})$ i zdrowych dziewcząt $(1,09 \pm 0,57 \mathrm{pg} / \mathrm{ml})(\mathrm{p}<0,05)$ (tab. II, ryc. 2).

Najniższe średnie stężenia IL-2 w surowicy krwi obserwowano w grupie AN $(3,76 \pm 0,68 \mathrm{pg} / \mathrm{ml})$, następnie $\mathrm{w}$ grupie otyłych $(10,66 \pm 3,45 \mathrm{pg} / \mathrm{ml})$ i zdrowych dziewcząt $(18,07 \pm 4,15 \mathrm{pg} / \mathrm{ml})(\mathrm{p}<$ $0,05)$ (tab. II, ryc. 3).

Porównując stężenia badanych cytokin u dziewcząt otyłych w porównaniu do zdrowych, wykazano, że średnie stężenia IL-1 $\alpha$ i IL-2 w surowicy krwi były istotnie statystycznie niższe $(\mathrm{p}<0,05)$ w grupie otyłych dziewcząt w porównaniu do grupy zdrowych (tab. II).

Badając stężenia insuliny we krwi, stwierdzono, że średnie stężenie insuliny w surowicy krwi $\mathrm{u}$ dziewcząt $\mathrm{z}$ jadłowstrętem psychicznym wynosiło $4,16 \pm 0,7 \mu \mathrm{IU} / \mathrm{ml}$ i było istotnie statystycznie niższe niż w grupie otyłych $(16,18 \pm 3,9 \mu \mathrm{IU} / \mathrm{ml} ; \mathrm{p}<$ $0,001)$ i zdrowych dziewcząt $(10,92 \pm 4,5 \mu \mathrm{IU} / \mathrm{ml}$; $\mathrm{p}<0,05)$. Jedynie $u$ dwóch pacjentek $\mathrm{z}$ otyłością $\mathrm{i}$ jednej zdrowej stężenie insuliny w surowicy krwi było powyżej normy (norma: 2,6-24,9 $\mu \mathrm{IU} / \mathrm{ml}$ ). Średnie stężenie INS w surowicy krwi w grupie OT było istotnie statystyczne wyższe aniżeli $\mathrm{w}$ grupie ZD dziewcząt $(p<0,05)$ (tab. II).

Zaobserwowano, że średnie stężenie hsCRP w surowicy krwi u chorych z AN $(0,29 \pm 0,1 \mathrm{mg} / \mathrm{l})$ było najniższe i różniło się znamiennie statystyczne wyłącznie w porównaniu do grupy OT $(2,13 \pm$ $0,62 \mathrm{mg} / 1 ; \mathrm{p}<0,001$ ) (tab. II). U żadnej badanej z AN i ZD nie stwierdzono ponad normę (norma: 0-5 mg/l) stężenia hsCRP w surowicy krwi, natomiast $\mathrm{u}$ trzech dziewcząt otyłych stężenie hsCRP było podwyższone. Wykazano, że średnie stężenie hsCRP u OT było istotnie statystyczne wyższe niż u ZD $(0,72 \pm 0,29 \mathrm{mg} / \mathrm{l} ; \mathrm{p}<0,05)$ (tab. II). 
Tabela II. Średnie stężenia cytokin oraz insuliny i hCRP w surowicy krwi w badanych grupach dziewcząt; AN - grupa badanych z anorexia nervosa, OT - grupa dziewcząt z otyłością prostą, ZD - grupa dziewcząt zdrowych

Table II. Means of cytokines, insulin and hCRP serum concentrations in examined groups of girls; AN - group with anorexia nervosa, OT - group with simple obesity, ZD - healthy group

\begin{tabular}{|c|c|c|c|}
\hline & AN $(n=30)$ & OT $(n=30)$ & $\mathrm{ZD}(\mathrm{n}=20)$ \\
\hline & $\begin{array}{c}\text { średnia } \pm 1,96 \mathrm{SE} \\
\text { (zakres) }\end{array}$ & $\begin{array}{c}\text { średnia } \pm 1,96 \text { SE } \\
\text { (zakres) }\end{array}$ & $\begin{array}{c}\text { średnia } \pm 1,96 \mathrm{SE} \\
\text { (zakres) }\end{array}$ \\
\hline IL-1 $\alpha \quad(p g / m l)$ & $\begin{array}{c}13,15 \pm 3,81 * \# \\
(0,6-38,8)\end{array}$ & $\begin{array}{l}4,72 \pm 1,4^{\circ} \\
(0,4-15,53)\end{array}$ & $\begin{array}{l}6,78 \pm 1,5 \\
(1,6-12,7)\end{array}$ \\
\hline IL-1 $\beta$ (pg/ml) & $\begin{array}{c}2,63 \pm 0,9 * * \\
(0,11-9,39)\end{array}$ & $\begin{array}{l}1,33 \pm 0,63 \\
(0,2-7,55)\end{array}$ & $\begin{array}{l}1,09 \pm 0,57 \\
(0,2-4,66)\end{array}$ \\
\hline IL-2 (pg/ml) & $\begin{array}{c}3,76 \pm 0,68 * \\
(1,38-9,64)\end{array}$ & $\begin{array}{c}10,66 \pm 3,49^{\circ} \\
(2,56-42,24)\end{array}$ & $\begin{array}{l}18,07 \pm 4,15 \\
(4,05-36,46)\end{array}$ \\
\hline Insulina ( $\mu \mid \mathrm{U} / \mathrm{ml})$ & $\begin{array}{c}4,16 \pm 0,74 * \# \\
(1,32-8,56)\end{array}$ & $\begin{array}{c}16,18 \pm 3,90^{\circ} \\
(3,6-45,9)\end{array}$ & $\begin{array}{c}10,92 \pm 4,53 \\
(3,7-48,27)\end{array}$ \\
\hline hsCRP (mg/l) & $\begin{array}{c}0,29 \pm 0,09 \# \\
(0,14-1,44)\end{array}$ & $\begin{array}{c}2,13 \pm 0,62^{\circ} \\
(0,43-5,9)\end{array}$ & $\begin{array}{l}0,72 \pm 0,29 \\
(0,21-2,63)\end{array}$ \\
\hline
\end{tabular}

$* \mathrm{p}<0,05$ AN vs ZD $\quad * * \mathrm{p}<0,05$ AN vs 0T i ZD

$\# p<0,001$ AN vs 0T ${ }^{\circ} \mathrm{p}<0,05$ OT vs ZD

Wykres ramkowy dla grup

Zmienna:

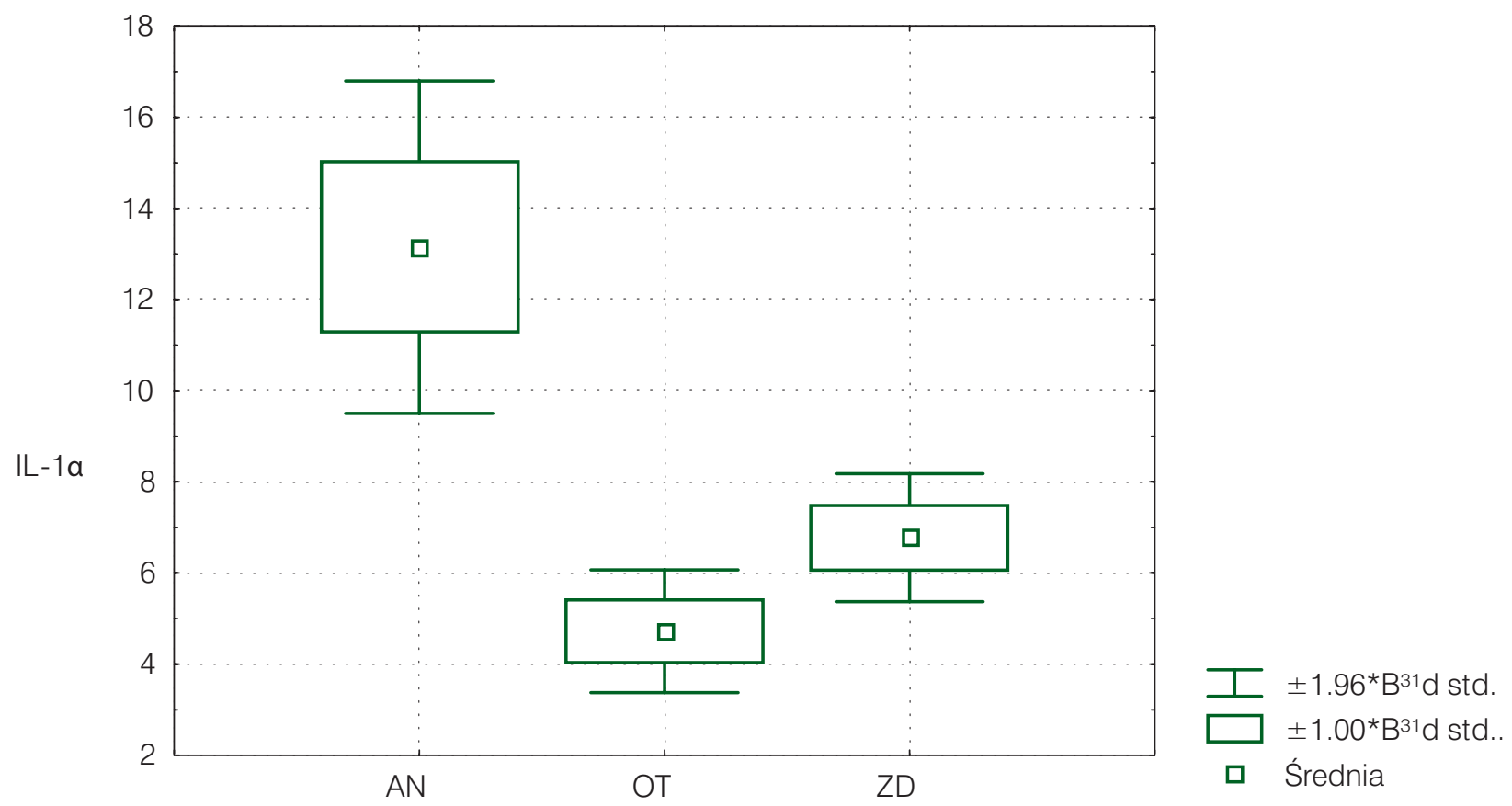

GRUPA

Ryc. 1. Średnie stężenia IL-1 $\alpha$ (pg/ml) w surowicy krwi w badanych grupach dziewcząt; AN - grupa z anorexia nervosa, OT - grupa otyłych, ZD - grupa zdrowych

Fig. 1. Mean IL-1 $\alpha$ (pg/ml) serum concentrations in examined groups of girls; $A N$-group with anorexia nervosa, $O T$ - group with simple obesity, $\mathrm{ZD}$ - healthy group $p<0,05$ AN vs $Z D ; \quad p<0,001$ AN vs OT 


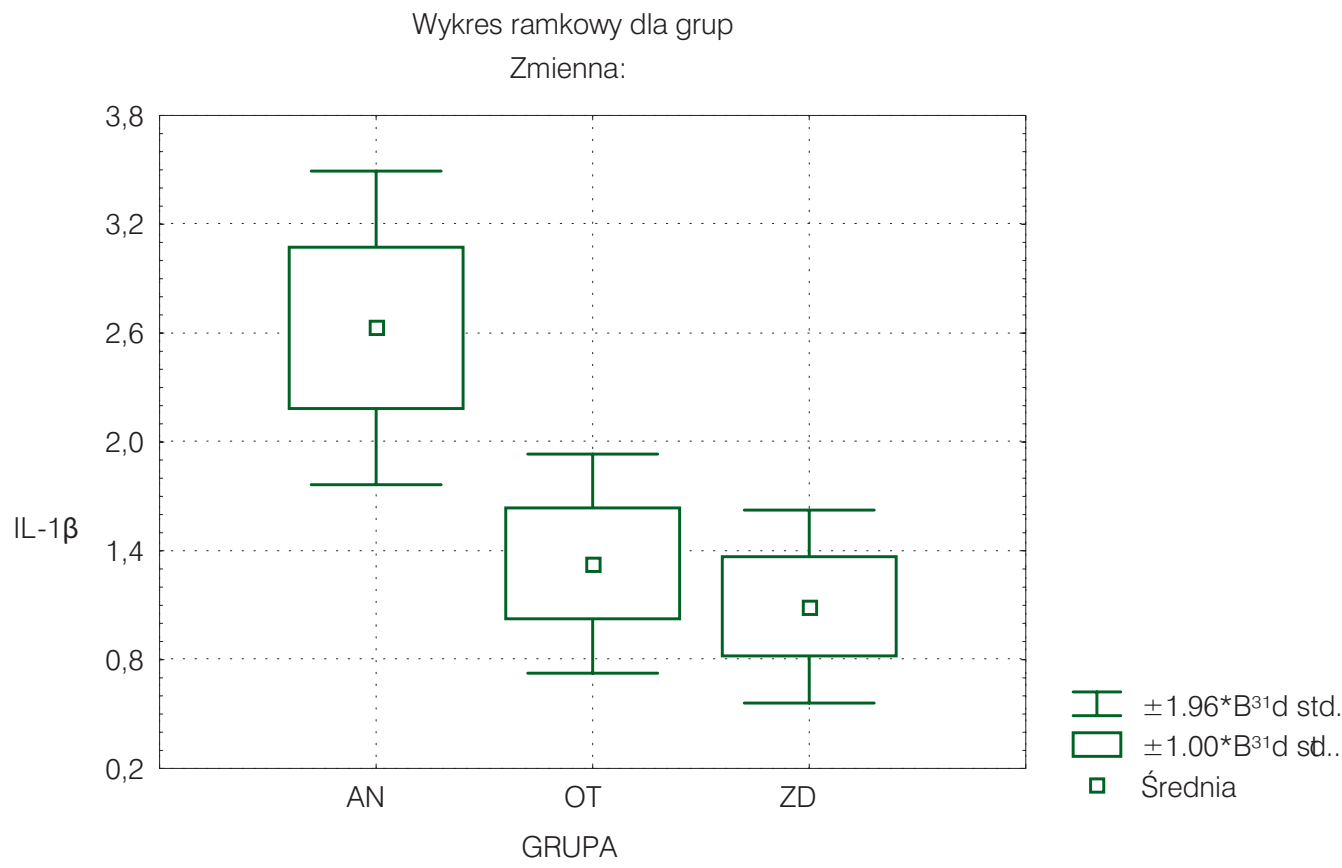

Ryc. 2. Średnie stężenia IL-1ß (pg/ml) w surowicy krwi w badanych grupach dziewcząt; AN - grupa z anorexia nervosa, OT - grupa otyłych, ZD - grupa zdrowych

Fig. 2. Mean IL-1 $\beta$ (pg/ml) serum concentrations in examined groups of girls; AN - group with anorexia nervosa, OT - group with simple obesity, ZD - healthy group $\mathrm{p}<0,05$ AN vs OT i ZD

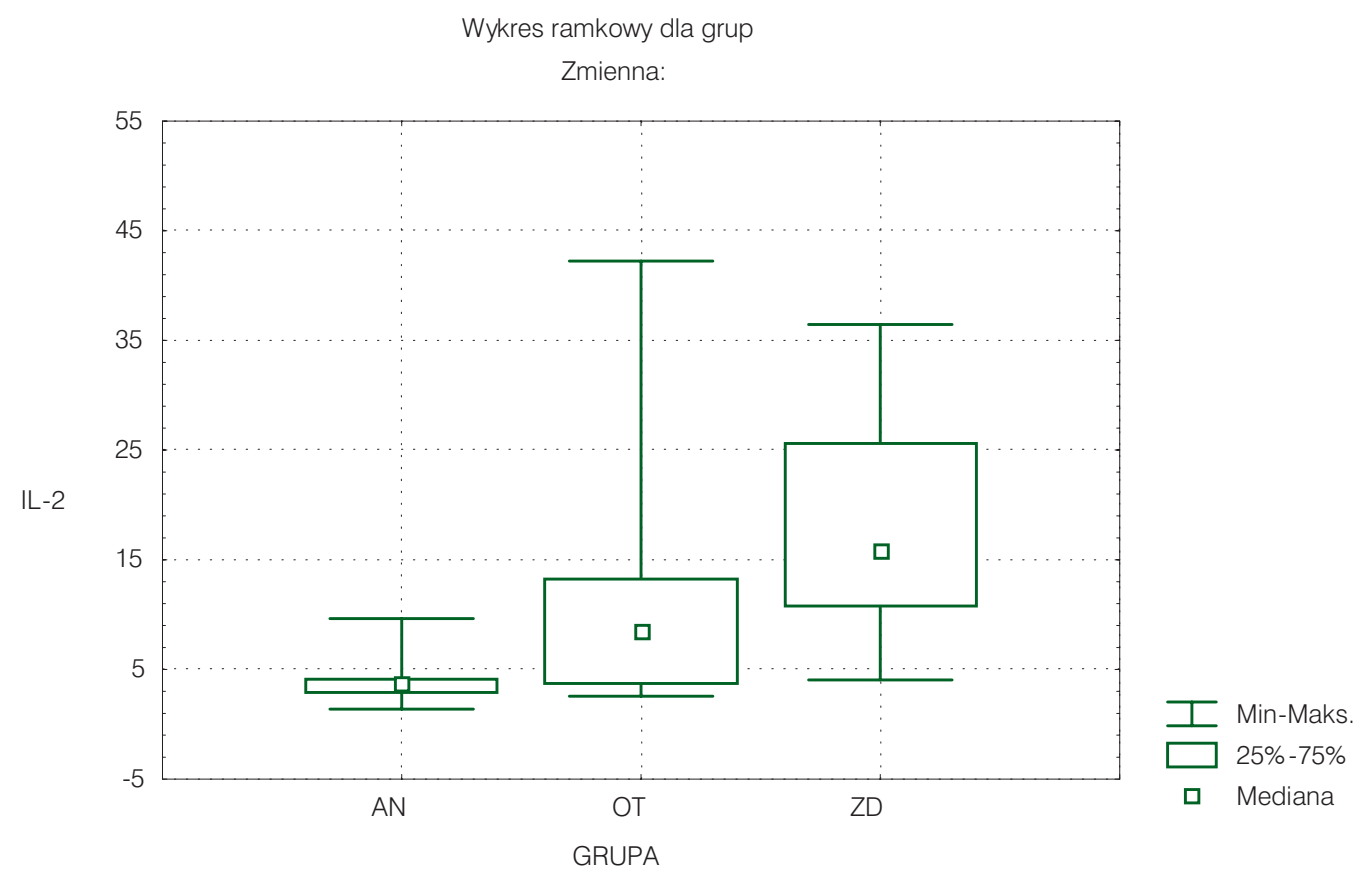

Ryc. 3. Średnie stężenia IL-2 (pg/ml) w surowicy krwi w badanych grupach dziewcząt; AN - grupa z anorexia nervosa, OT - grupa otyłych, ZD - grupa zdrowych

Fig. 3. Mean IL-2 (pg/ml) serum concentrations in examined groups of girls; AN - group with anorexia nervosa, OT - group with simple obesity, ZD - healthy group

$p<0,05$ AN vs OT i ZD 
Nie znaleziono zależności pomiędzy długością trwania choroby u dziewcząt z AN a stężeniem we krwi badanych cytokin, INS i hsCRP.

Analiza zależności pomiędzy stężeniem IL1a i IL-1 \& i IL-2 we krwi a masa ciała, BMI i wskaźnikiem Cole'a w grupie z anorexia nervosa, dziewczą $z$ otylościa $i$ zdrowych oraz w calej badanej grupie

Nie stwierdzono korelacji pomiędzy stężeniem IL- $1 \alpha$ i IL-1 $\beta$ we krwi a masą ciała, BMI i wskaźnikiem Cole'a, zarówno u dziewcząt z AN, jak i w grupie OT i ZD. Wykazano natomiast istotne statystycznie ujemne korelacje pomiędzy stężeniem tych cytokin we krwi a wymienionymi parametrami w całej badanej grupie dziewcząt łącznie (AN, OT, ZD) (tab. III).

Natomiast dodatnie, znamienne statystycznie korelacje wykazano pomiędzy stężeniem IL-2 we krwi a BMI i wskaźnikiem Cole'a, ale także wyłącznie u wszystkich badanych (tab. III). W obrębie poszczególnych grup (AN, OT, ZD) nie było istotnych korelacji pomiędzy tymi parametrami.

Analiza korelacji pomiędzy stężeniem badanych cytokin a stężeniem insuliny $i$ hsCRP we krwi u dziewczą $z$ anorexia nervosa, zotylościa $i$ zdrowych oraz w calej badanej grupie

W całej badanej grupie dziewcząt łącznie (AN, OT, ZD) zaobserwowano silną dodatnią korelację pomiędzy stężeniem we krwi hsCRP oraz insuliny a masą ciała $(r=0,71, p<0,01 ; r=0,55, p<0,001$ odpowiednio) a BMI $(\mathrm{r}=0,84, \mathrm{p}<0,001 ; \mathrm{r}=0,74, \mathrm{p}<$ 0,001 odpowiednio) i wskaźnikiem Cole'a $(\mathrm{r}=0,82$, $\mathrm{p}<0,001 ; \mathrm{r}=0,73, \mathrm{p}<0,01$ odpowiednio).
W grupie AN stwierdzono dodatnią istotnie statystyczną korelację pomiędzy stężeniem hsCRP a BMI $(r=0,44 ; p<0,05)$. Nie było takich zależności pomiędzy hsCRP a masą ciała ani wskaźnikiem Cole’a. Podobnie nie było zależności statystycznie znamiennych pomiędzy stężeniem INS we krwi a masą ciała, BMI ani wskaźnikiem Cole'a w grupie dziewcząt z AN.

Wykazano znamienne statystycznie ujemne korelacje pomiędzy stężeniem IL-1 $\alpha(\mathrm{r}=-0,28 ; \mathrm{p}<$ $0,05)$ i IL-1 $\beta(r=-0,42 ; p<0,05)$ oraz dodatnie pomiędzy stężeniem IL-2 $(\mathrm{r}=0,35 ; \mathrm{p}<0,05)$ a stężeniem INS we krwi, ale tylko u wszystkich badanych łącznie. W obrębie grup badanych dziewcząt (AN i ZD) nie zanotowano korelacji znamiennych statystycznie pomiędzy stężeniem insuliny a stężeniem badanych cytokin we krwi.

W całej badanej grupie dziewcząt łącznie wykazano statystycznie istotne ujemne korelacje pomiędzy stężeniem hsCRP a stężeniem IL- $1 \alpha(\mathrm{r}=-0,46$; $\mathrm{p}<0,001)$ i IL-1 $\beta(\mathrm{r}=-0,29 ; \mathrm{p}<0,05)$ oraz dodatnie pomiędzy stężeniem hsCRP a stężeniem IL-2 $(r=0,29 ; p<0,05)$ we krwi. Nie było zależności dotyczących tych parametrów w obrębie grupy dziewcząt $\mathrm{z}$ jadłowstrętem psychicznym, otyłych i zdrowych.

\section{Dyskusja}

Jadłowstręt psychiczny to przewlekłe schorzenie, w którym głównym objawem jest niedożywienie, często skrajne wyniszczenie, spowodowane celowym ograniczaniem spożywania pokarmu przez chorą osobę. Od dawna trwają badania w celu poszukiwania czynników patogenetycznych prowa-

Tabela III. Korelacje pomiędzy stężeniami badanych cytokin we krwi $(\mathrm{pg} / \mathrm{ml})$ a masą ciała, BMl i wskaźnikiem Cole’a Table III. Correlations between serum examined cytokines concentrations (pg/ml) and weight, BMI and Cole index

\begin{tabular}{|c|c|c|c|c|c|c|}
\hline \multirow{2}{*}{} & \multicolumn{3}{|c|}{ AN } & \multicolumn{3}{c|}{ Cała badana grupa } \\
\cline { 2 - 7 } & $\begin{array}{c}\mathrm{IL}-1 \alpha \\
(\mathrm{pg} / \mathrm{ml})\end{array}$ & $\begin{array}{c}\mathrm{IL}-1 \beta \\
(\mathrm{pg} / \mathrm{ml})\end{array}$ & $\begin{array}{c}\mathrm{IL}-2 \\
(\mathrm{pg} / \mathrm{ml})\end{array}$ & $\begin{array}{c}\mathrm{IL}-1 \alpha \\
(\mathrm{pg} / \mathrm{ml})\end{array}$ & $\begin{array}{c}\mathrm{IL}-1 \beta \\
(\mathrm{pg} / \mathrm{ml})\end{array}$ & $\begin{array}{c}\mathrm{IL}-2 \\
(\mathrm{pg} / \mathrm{ml})\end{array}$ \\
\hline m. ciała & $\mathrm{r}=0,01$ & $\mathrm{r}=0,22$ & $\mathrm{r}=-0,24$ & $\mathrm{r}=-0,32$ & $\mathrm{r}=-0,25$ & $\mathrm{r}=0,14$ \\
$(\mathrm{~kg})$ & $\mathrm{p}=0,96$ & $\mathrm{p}=0,29$ & $\mathrm{p}=0,24$ & $\mathrm{p}<0,05$ & $\mathrm{p}<0,05$ & $\mathrm{p}=0,24$ \\
BMl & $\mathrm{r}=0,19$ & $\mathrm{r}=-0,02$ & $\mathrm{r}=-0,14$ & $\mathrm{r}=-0,41$ & $\mathrm{r}=-0,34$ & $\mathrm{r}=0,33$ \\
$\left(\mathrm{~kg} / \mathrm{m}^{2}\right)$ & $\mathrm{p}=0,29$ & $\mathrm{p}=0,92$ & $\mathrm{p}=0,46$ & $\mathrm{p}<0,001$ & $\mathrm{p}<0,05$ & $\mathrm{p}<0,05$ \\
wskaźnik & $\mathrm{r}=0,21$ & $\mathrm{r}=0,003$ & $\mathrm{r}=-0,13$ & $\mathrm{r}=-0,37$ & $\mathrm{r}=-0,33$ & $\mathrm{r}=0,30$ \\
Cole'a (\%) & $\mathrm{p}=0,28$ & $\mathrm{p}=0,98$ & $\mathrm{p}=0,51$ & $\mathrm{p}<0,001$ & $\mathrm{p}<0,05$ & $\mathrm{p}<0,05$ \\
\hline
\end{tabular}

AN - grupa z anorexia nervosa 
dzących do rozwoju anorexia nervosa. Holden i wsp. [1] sugerują, że cytokiny mogą być fundamentalnymi regulatorami metabolizmu w jadłowstręcie psychicznym i bulimii. Proponują tzw. psychoneuroimmunologiczny model patogenetyczny zaburzeń odżywiania. Według nich do rozwoju jadłowstrętu psychicznego czy bulimii może prowadzić dysregulacja systemu immunologicznego. Uważają, że utrzymywanie się przez dłuższy czas zwiększonej syntezy cytokin prozapalnych może indukować kaskadę biochemicznych efektów w OUN, wpływając na sekrecję neurotransmitterów, neuropeptydów, neurohormonów i obwodowych hormonów, co ma znaczenie w etiopatogenezie AN. Inni autorzy także uważają, że jadłowstręt psychiczny może być indukowany przez cytokiny prozapalne, w tym przez IL-1, IL-6, TNF- $\alpha$, IFN- $\gamma$. Mimo iż u pacjentów z zaburzeniami odżywiania odnotowuje się pewne zmiany w produkcji cytokin, to nie jest jeszcze do końca wyjaśnione, czy ma to wpływ na początek ujawnienia się choroby [22, 23].

Wyniki badań dotyczących stężeń cytokin u chorych z zaburzeniami odżywiania można podzielić na dwie kategorie. Są to badania oceniające stężenie cytokin krążących w płynach ustrojowych oraz te, w których oceniano sekrecję cytokin spontaniczną lub indukowaną mitogenami (lipopolysaccharide, LPS, phytohemaglutinin A, PHA) in vitro w liniach komórek jednojądrzastych krwi obwodowej (peripheral blood mononuclear cells, PBMCs). Najczęściej porównywano wyniki uzyskane u chorych z zaburzeniami odżywiania do wyników uzyskanych u osób zdrowych. Tylko nieliczni autorzy [24] przeprowadzali badania stężeń cytokin w płynie mózgowo-rdzeniowym u osób z zaburzeniami odżywiania, ponieważ te badania są trudniejsze do wykonania i bardziej obciążające dla chorego. Nie można także pominąć badań eksperymentalnych $\mathrm{w}$ modelach prowadzonych in vitro i in vivo u zwierząt doświadczalnych.

Porównywanie wyników oznaczeń cytokin we krwi do wyników przedstawianych przez poszczególnych autorów może sprawić pewne trudności. Autorzy posługiwali się bowiem różnymi metodami laboratoryjnymi. Jedni używali do oznaczeń metody ELISA (enzyme-linked immunosorbent assay) $[8,25,26]$ podobnie jak my, inni metody RIA ( $r a-$ dioimmunnoassay) $[6,27,28]$, jeszcze inni metody IRMA (immunoradioassay) [27]. Te metody pozwalają wyłącznie na pomiar immunoreaktywności surowicy i oceniają biologicznie nieaktywne cytokiny lub tylko ich fragmenty. Inni z kolei stosowali meto- dę BIA (bioassay), która jest używana celem oceny aktywności biologicznej cytokin [10, 30, 31].

Nasze badanie wykazało znamiennie wyższe stężenia we krwi IL-1 u chorych z anorexia nervo$s a$ w porównaniu do dziewcząt otyłych i zdrowych. Inni autorzy $[25,26]$ także stwierdzali wyższe stężenia we krwi lub większą produkcję tego białka po stymulacji mitogenem u chorych z AN, ale nie wszyscy podzielali to zdanie, wykazując w swoich badaniach brak różnic pomiędzy grupą z AN a zdrowymi $[6,14,22,32,33]$.

Allende i wsp. [25] przeprowadzili badania w grupie 40 dziewcząt chorujących na AN (śr. wiek $16,9 \pm 2.9$ lat), dzieląc je pod względem wskaźnika masy ciała na podgrupę z $\mathrm{BMI} \leq 17,5 \mathrm{~kg} / \mathrm{m}^{2}$ oraz podgrupę z BMI $\geq 17,5 \mathrm{~kg} / \mathrm{m}^{2}$. U dziewcząt z AN i $\mathrm{BMI} \leq 17,5 \mathrm{~kg} / \mathrm{m}^{2}$ wykazali, podobnie jak my w niniejszym badaniu, istotnie wyższe stężenia IL-1 w surowicy krwi $(0,27 \pm 0,28 \mathrm{ng} / \mathrm{ml})$ w porównaniu do grupy dziewcząt zdrowych $(0,05 \pm 0,07 \mathrm{ng} / \mathrm{ml}$; $\mathrm{p}<0,05)$. Nie było natomiast różnic statystycznie znamiennych pomiędzy stężeniami IL-1 $\beta$ w surowicy krwi w grupie dziewcząt $\mathrm{z}$ AN i BMI $\geq 17,5 \mathrm{~kg} /$ $\mathrm{m}^{2}(0,19 \pm 0,3 \mathrm{ng} / \mathrm{ml})$ w porównaniu do zdrowych. Te wyniki mogą świadczyć o zależności pomiędzy stanem odżywienia a stężeniem we krwi IL-1 $\beta$.

W naszym badaniu także wykazano ujemną korelację pomiędzy stężeniem nie tylko IL-1 $\beta$, ale i IL- $1 \alpha$ we krwi a masą ciała, BMI oraz wskaźnikiem Cole'a w całej badanej grupie dziewcząt łącznie, tj. u chorych z AN, otyłych i zdrowych. Nie było takiej zależności w obrębie poszczególnych grup, zapewne $\mathrm{z}$ uwagi na niewielki w tych grupach rozrzut wartości masy ciała.

Inni autorzy [26] badali in vitro zdolność do produkcji interleukiny - $1 \beta$ przez komórki PBMCs, uzyskane od 40 młodych dziewcząt (śr. wiek: 13-18 lat) cierpiących na postać restrykcyjną i bulimiczno-oczyszczającą jadłowstrętu psychicznego $\mathrm{w}$ momencie przyjęcia do szpitala oraz po miesiącu leczenia, w porównaniu do 35 zdrowych dziewcząt. Zanotowali istotnie większą produkcję tej cytokiny u chorych z AN, zarówno na początku terapii (śr. 888,3 pg/ml), jak i po miesiącu leczenia (śr. 709,5 pg/ml), w stosunku do zdrowych (śr. 30,9 $\mathrm{pg} / \mathrm{ml} ; \mathrm{p}<0,001)$. Krótki okres leczenia dziewcząt z AN wpłynął co prawda na istotny przyrost masy ciała i wskaźnika BMI, ale nie spowodował wzrostu masy ciała i BMI do wartości obserwowanych u dziewcząt zdrowych. Można więc przypuszczać, że właśnie dlatego produkcja IL-1 $\beta$ u chorych była podobna przed, jak i po leczeniu. 
Interleukina 1 należy do cytokin, które odgrywają rolę w mechanizmach poboru pokarmu. IL-1 powoduje spadek apetytu i tym samym zmniejszenie poboru pokarmu. Wskazują na to wyniki badań eksperymentalnych prowadzonych na modelach zwierzęcych. Przewlekłe dokomorowe wstrzyknięcia IL-1 szczurom przyczyniały się do spadku poboru pokarmu w porze nocnej w zależności od sposobu dawkowania [34]. Obserwacje wskazują, że ta cytokina może wpływać bezpośrednio jak i pośrednio na ośrodkowy układ nerwowy.

Udowodniono, że IL-1 działa bezpośrednio na neurony zlokalizowane $\mathrm{w}$ podwzgórzu, włączone w regulację zachowań żywieniowych i apetytu. Uważa się, że może być produkowana przez specyficzne pola OUN i działa lokalnie bez towarzyszącego wzrostu poziomu w surowicy czy mózgu. Licino i wsp. [24] nie wykazali korelacji pomiędzy obwodowym a centralnym poziomem krążącej IL-1. Neurony jądra łukowatego podwzgórza odgrywają osiową rolę $\mathrm{w}$ regulacji homeostazy energetycznej i poborze pokarmu. Niektórzy autorzy [35] twierdzą, że właśnie nadmierna lokalna produkcja IL-1 w specyficznych regionach mózgu może być odpowiedzialna za zmniejszenie apetytu i poboru pokarmu.

Pośrednie efekty działania IL-1 mogą być z kolei związane $\mathrm{z}$ interakcją, jaka następuje pomiędzy tą cytokiną a neuropeptydami i neurotransmitterami. Dysregulacja profilu wydzielniczego cytokin prozapalnych, w tym IL-1, zaburza funkcjonowanie systemu katecholaminergicznego i opioidowego, które jak wiadomo mają znaczenie w rozwoju i przebiegu AN. Udowodniono, że IL-1 $\beta$ aktywuje oś podzwgórzowo-przysadkowo-nadnerczową, a także metabolizm norepinefryny i adrenaliny oraz katabolizm serotoniny $\mathrm{w}$ przednim podwzgórzu u szczurów [36]. Ponadto IL-1 $\beta$ podnosi stężenie katecholamin w osoczu, co też skutkuje supresją poboru pokarmu [23].

Licino i wsp. [24] dokonywali pomiarów poziomu IL-1 w płynie mózgowo-rdzeniowym u osób $z$ bulimią. W ostrej fazie choroby stwierdzali wzrost stężenia IL-1 w płynie mózgowo-rdzeniowym i we krwi oraz powrót do normalnych wartości po uzyskaniu przyrostu masy ciała. IL-1 stymuluje produkcję ACTH [23]. To mogłoby wyjaśniać utrzymujący się u chorych z AN stan hiperkortyzolemii.

Wyniki cytowanych badań oraz nasze obserwacje, iż u pacjentek z AN są istotnie wyższe stężenia IL-1 we krwi aniżeli u ZD, mogą wskazywać, że ta cytokina może być odpowiedzialna za zahamowanie poboru pokarmu u tych chorych. Nie wiadomo jednak nadal, czy podwyższenie produkcji IL-1 jest pierwotne, będąc jednym z czynników sprawczych ujawnienia się lub rozwoju objawów AN, czy raczej jest zjawiskiem wtórnym do niedożywienia.

Odmienne wyniki oznaczeń IL-1 we krwi lub in vitro $\mathrm{w}$ kulturach komórek mononuklearnych u osób cierpiących na zaburzenia odżywiania uzyskali inni autorzy.

Bessler i wsp. [37] nie zanotowali różnic w produkcji IL-1 przez limfocyty, zarówno spontanicznej, jak i stymulowanej lipopolisacharydami u pacjentów z AN w porównaniu do zdrowych. Sugerują, że surowica tych chorych może zawierać jakiś czynnik lub czynniki stymulujące produkcję cytokin, które są w stanie w razie potrzeby skompensować ich niską produkcję.

Vaisman i wsp. [14], badając małą liczebnie, bo 10-osobową grupę dziewcząt z AN (wiek: 13,5-18 lat), stwierdzili również, że spontaniczna produkcja IL-1 przez PBMCs nie różniła się u nich istotnie w stosunku do grupy ZD. U chorych z AN wykazali ponadto zaburzoną granulopoezę, manifestującą się in vitro redukcją zarówno GM-CFC (granulocytemacrophage colony-forming cells), jak i GM-CSF (granulocyte- macrophage colony- stimulating factor). Autorzy wnioskują, że zmniejszone stężenie IL-1, które jest opisywane również w stanach skrajnego wyniszczenia u dzieci z nabytym niedożywieniem białkowym (kwashiorkor) lub białkowo-energetycznym (marasmus), u chorych z AN może być wyłącznie rezultatem zaburzeń równowagi białkowo-kalorycznej organizmu.

Inni autorzy [8] badali stężenie IL-1 $\alpha$ i IL-1 $\beta$ w surowicy oraz zdolność do syntezy tych białek $\mathrm{u}$ dorosłych pacjentek z AN przed i w trakcie realimentacji, podczas uzyskiwania przez nie przyrostu masy ciała. Stężenie obu cytokin w surowicy krwi badane metodą ELISA oraz ich spontaniczne wydzielanie było niewykrywalne zarówno w grupie z AN, jak i u ZD. Nie było istotnych statystycznie różnic $\mathrm{w}$ produkcji IL- $1 \alpha$ i IL-1 $\beta$ po stymulacji lipopolisacharydami pomiędzy grupami z AN i grupą zdrowych. Zaobserwowano natomiast istotny wzrost syntezy IL-1 $\alpha$ (z 60,2 $\pm 50,2 \mathrm{pg} / \mathrm{ml}$ do $157 \pm 77,0 \mathrm{pg} / \mathrm{ml} ; \mathrm{p}<0,01)$ oraz IL-1 $\beta$ (z $302 \pm 173$ $\mathrm{pg} / \mathrm{ml}$ do $1004 \pm 607 \mathrm{pg} / \mathrm{ml} ; \mathrm{p}<0,01)$ wraz z przyrostem masy ciała do $75 \%$ należnej u chorych z AN. Zwrócono uwagę, że produkcja IL-1 u tych chorych po zwiększeniu masy ciała była wyższa niż u zdrowych, choć bez istotności statystycznej. Według autorów może to dowodzić wzmożonej aktywności mononuklearów do produkcji cytokin w okre- 
sie realimentacji. Wnioskują, że nie bezwzględna wartość masy ciała, ale raczej przyrost jego masy mogą być czynnikami sprzyjającymi poprawie produkcji cytokin.

Brambilla i wsp. [22] także oceniali stężenia IL$1 \beta \mathrm{w}$ surowicy krwi przed- i po rozpoczęciu terapii, ale badania prowadzili $\mathrm{w}$ dwu grupach kobiet $\mathrm{z}$ zaburzeniami odżywiania. Były to kobiety z AN, w tym 9 kobiet z postacią restrykcyjną (AN-R) i 17 z postacią bulimiczno-oczyszczającą AN (AN-BP) oraz 24 kobiety z bulimią (BN). Oznaczenia stężeń IL-1 metodą IRMA były wykonywane przed rozpoczęciem leczenia, po miesiącu, a następnie po 3 miesiącach od wdrożenia terapii, na którą składała się psychoterapia i leczenie farmakologiczne (fluoxetine, amineptine lub fluvoxamine). Wskaźnik BMI chorych z AN był znamiennie statystycznie niższy niż u ZD. BMI chorych na BN nie odbiegało od BMI kobiet zdrowych. Wyłącznie w grupie AN-R nastąpił wzrost BMI pod wpływem leczenia. Autorzy nie wykazali różnic istotnych statystycznie $\mathrm{w}$ stężeniach IL-1 $\beta$ w surowicy krwi pomiędzy grupą z AN, a także BN a grupą zdrowych. Nie obserwowali też istotnych zmian w stężeniach tej cytokiny we krwi po miesiącu i po 3 miesiącach leczenia u chorych w obu grupach (AN i BN). Nie stwierdzili korelacji pomiędzy stężeniem tej cytokiny a BMI. Zaskakujące jest to, że nie doszło do zmian w stężeniach IL-1 podczas leczenia farmakologicznego. Limfocyty posiadają bowiem receptory serotoninergiczne i dopaminergiczne, więc należałoby się spodziewać wpływu inhibitorów zwrotnego wychwytu serotoniny czy inhibitorów dopaminy na czynność limfocytów. Według autorów uzyskane wyniki pozwalają wykluczyć tezę, iż oznaczane cytokiny mogą modulować przebieg choroby i odpowiedź na terapię w zaburzeniach odżywiania.

Większość autorów badających IL-1 u chorych z zaburzeniami odżywiania oznaczała podklasę IL1ß. Raymond i wsp. [18] oceniali natomiast stężenie IL-1 $\alpha$, ale nie w surowicy, lecz w supernatantach kultury komórek PBMCs zarówno niestymulowanych, jak i stymulowanych konkawaliną $\mathrm{A}$. Badanie przeprowadzili u 35 kobiet z zaburzeniami odżywiania, w tym u 19 z AN i u 16 z BN, porównując podobnie jak my uzyskane wyniki do wyników w grupie kobiet otyłych i zdrowych. Spontaniczna produkcja IL-1 $\alpha$ była podobna u badanych we wszystkich grupach, ale wykazano znamiennie wyższą produkcję tej cytokiny po stymulacji konkawaliną A u kobiet OT w porównaniu do ZD $(785 \pm$ $506 \mathrm{pg} / \mathrm{ml}$ vs $481 \pm 206 \mathrm{pg} / \mathrm{ml} ; \mathrm{p}=0,028)$. Podobne wyniki uzyskali wcześniej Bessler i wsp. [32].
W niewielu pracach autorzy odnoszą wyniki oznaczanych cytokin do parametrów stanu odżywienia, tj. masy ciała, BMI czy wskaźnika Cole'a. W naszym badaniu celowo dobrano grupę porównawczą dziewcząt otyłych, ponieważ w obrębie jednej grupy badanych, np. z AN czy zdrowych, rozrzut masy ciała jest niewielki, stąd trudno jest stwierdzić $\mathrm{z}$ całą pewnością, czy istnieje zależność pomiędzy badanymi we krwi poziomami cytokin a stanem odżywienia badanych. W przypadku IL-1 $\alpha$ i IL-1 $\beta$ stwierdziliśmy istotną statystycznie, ujemną korelację pomiędzy stężeniami tych białek we krwi a masą ciała, BMI i wskaźnikiem Cole'a u wszystkich badanych łącznie. Być może nadmierna synteza tych cytokin u osób niedożywionych z jadłowstrętem psychicznym następuje głównie poza tkanką thuszczową, tj. w makrofagach, monocytach, fibroblastach czy może jeszcze w innych komórkach, zlokalizowanych poza tkanką thuszczową.

Drugą ocenianą przez nas cytokiną była IL-2. Stężenie IL-2 w surowicy krwi było istotnie niższe $\mathrm{w}$ grupie $\mathrm{z}$ anorexia nervosa $\mathrm{w}$ porównaniu zarówno do dziewcząt otyłych, jak i zdrowych. Podobne wyniki uzyskali inni autorzy $[6,13]$, którzy badali jednak wyłącznie kobiety z AN i zdrowe. Licinio i wsp. [13] wykonywali badania w bardzo małych grupach, bo zaledwie u 7 kobiet z AN i u 7 zdrowych, ale wykazali, podobnie jak my, istotnie niższe stężenia tej interleukiny u chorych z AN.

Inni autorzy [6], którzy badali kobiety z AN (śr. wiek: $20,1 \pm 1,9$ lat) i zdrowe (śr. wiek: $23,7 \pm 2,7$ lat), także stwierdzili istotnie niższe stężenia IL-2 w surowicy krwi w grupie z AN w porównaniu do zdrowych $(189,3 \pm 39,1 \mathrm{pg} / \mathrm{ml}$ vs $482,4 \pm 129,0$ $\mathrm{pg} / \mathrm{ml} ; \mathrm{p}=0,015)$.

Allende i wsp. [25] oceniali in vitro zdolność komórek PBMCs do produkcji IL-2 u kobiet z AN pod wpływem różnych stymulatorów (endotoksyny A: EA, fitohemaglutyniny: PHA i anti-CD3). Zanotowali niższą niż u kobiet zdrowych produkcję tej cytokiny w grupie kobiet z AN, zwłaszcza tych, których BMI było najniższe $\left(<17,5 \mathrm{~kg} / \mathrm{m}^{2}\right)$, choć różnica ta nie była istotna statystycznie.

Interesujące badanie in vitro przeprowadzili Bessler i wsp. [37]. Wykazali znamiennie statystycznie obniżoną zdolność do produkcji IL-2 przez komórki PBMCs u chorych z AN w porównaniu do zdrowych. Jednakże dodanie surowicy uzyskanej od pacjentów z AN do komórek PBMCs zdrowych osób spowodowało zwiększoną aktywność stymulacyjną tych komórek do produkcji IL-2. Autorzy sugerują, że surowica osób z anorexia nervosa zawiera jakiś 
czynnik lub czynniki stymulujące produkcję cytokin, które kompensują niską produkcję tej cytokiny przez komórki jednojądrzaste.

IL-2 jest uwalniana głównie przez aktywowane limfocyty $\mathrm{T}$, najczęściej przez Th-1. Obniżone jej stężenie we krwi u chorych z AN może odzwierciedlać zmniejszoną aktywność limfocytów, co niekoniecznie jest specyficzne dla patofizjologii zaburzeń odżywiania. Licinio i wsp. [24] wykazali znamienną statystycznie korelację pomiędzy liczbą leukocytów a poziomem krążącej we krwi IL-2. Zasugerowali, że obniżone stężenie IL-2 u tych chorych może wynikać z leukopenii, często obserwowanej u pacjentów z AN i jest wyrazem depresji układu immunologicznego. Udowodniono, że już tydzień głodzenia prowadzi do zmniejszenia produkcji IL-2 przez PBMCs [38].

Nasze badanie wykazało istotną statystycznie dodatnią zależność pomiędzy stężeniem krążącej we krwi IL-2 a BMI i wskaźnikiem Cole'a w całej badanej grupie dziewcząt. Niższemu BMI towarzyszyły niższe stężenia IL-2 we krwi. Bessler i wsp. [37] zaobserwowali, że produkcja IL-2 u chorych z AN jest odwracalna i wzrasta po realimentacji wraz ze wzrostem masy ciała. Zatem przyczyną dysregulacji immunologicznej w zakresie tej cytokiny mogłoby być właśnie niedożywienie.

Badania na temat oceny stężeń IL-2 we krwi w AN są nieliczne. Nagata i wsp. [39] opisali znamiennie niższy poziom rozpuszczalnego receptora IL-2 we krwi u pacjentów z postacią restrykcyjną $\mathrm{AN}$, lecz nie z postacią bulimiczno-oczyszczającą w porównaniu do zdrowych. Inni autorzy [11] nie stwierdzali różnic w tym zakresie.

Wiadomo już, że IL-2 pochodzi z czterech głównych źródeł. Jest syntetyzowana przez komórki błony śluzowej jelit, krwinki białe, ośrodkowy układ nerwowy i adipocyty. Można przypuszczać, że obniżone poziomy tej cytokiny we krwi mogą zależeć od deficytu składników pokarmowych, wynikającego z atrofii lub uszkodzenia błony śluzowej jelit spowodowanego przewlekłym głodzeniem oraz towarzyszącym mu niedożywieniem [6]. Już nawet niewielkie zmiany masy ciała u pacjentów z AN przed i po realimentacji mają wpływ na profil krążącej IL-2 i dysregulację jej syntezy. Potrzebne by były jednak długofalowe obserwacje u chorych z AN przed i po leczeniu w zakresie relacji pomię- dzy cytokinami a parametrami takimi, jak depresja czy stężenia niektórych neurotransmiterów [6].

Brakuje doniesień na temat zależności pomiędzy stężeniami insuliny a IL-1 i IL-2 we krwi. Nasze badania wykazały istotną statystycznie ujemną korelację pomiędzy stężeniem IL- $1 \alpha$ i IL- $1 \beta$ oraz dodatnią pomiędzy stężeniem IL-2 a stężeniem insuliny we krwi w całej badanej grupie. Nie było takich zależności ani w grupie z AN, ani u OT i ZD dziewcząt.

Poprzednie nasze badania u dziewcząt z AN wykazały we krwi wyższe niż u zdrowych stężenia hormonu tkanki tłuszczowej o korzystnym działaniu przeciwcukrzycowym i przeciwmiażdżycowym, tj. adiponektyny, oraz niższe niż u zdrowych i otyłych dziewcząt stężenia hormonu zwiększającego insulinoporność, tj. rezystyny [40,41].

Można domniemywać, że mechanizmy obejmujące zmiany $\mathrm{w}$ produkcji cytokin mogą odgrywać rolę $\mathrm{w}$ procesach adaptacyjnych do nietypowej dla organizmu sytuacji spowodowanej niedożywieniem. Zapewne też mechanizmy kompensacyjne są odmienne w chorobie o charakterze przewlekłym aniżeli w chorobie trwającej krótko, o przebiegu ostrym [26].

\section{Wnioski}

1. U dziewcząt $\mathrm{z}$ jadłowstrętem psychicznym obserwuje się istotnie wyższe stężenia IL- $1 \alpha$ i IL-1 $\beta$ we krwi aniżeli u otyłych i zdrowych, co być może jest czynnikiem wpływającym na zahamowanie poboru pokarmu u tych chorych.

2. Obserwowane $u$ chorych $z$ jadłowstrętem psychicznym istotnie niższe stężenia IL-2 we krwi aniżeli u otyłych i zdrowych mogą wynikać z depresji układu immunologicznego. Dodatnia zależność pomiędzy stężeniem tej cytokiny we krwi a stopniem odżywienia może świadczyć o tym, że przyczyną dysregulacji immunologicznej w zakresie tej cytokiny może być niedożywienie.

3. Ujemna korelacja pomiędzy stężeniem we krwi IL-1 $\alpha$ i IL-1 $\beta$ i dodatnia pomiędzy stężeniem IL-2 a stężeniem insuliny wyłącznie w całej badanej grupie, gdzie obserwuje się duży rozrzut wartości masy ciała, może dowodzić, że te cytokiny odgrywają rolę w modelowaniu insulinooporności zależnie od masy ciała. 


\section{REFERENCES/PIŚMIENNICTWO}

[1] Holden R.J., Pakula I.S: The role of tumor necrosis factor-alpha in the pathogenesis of anorexia and bulimia nervosa, cancer cachexia and obesity. Med. Hypotheses., 1996:47, 423-438.

[2] Jacobi D., Stanya K.J., Lee C.H.: Adipose tissue signaling by nuclear receptors in metabolic complications of obesity. Adipocyte., 2012:1, 4-12.

[3] Akdis M., Burgler S., Crameri R. et al.: Interleukins, from 1 to 37 , and interferon- $\gamma$ : receptors, functions, and roles in diseases. J. Allergy Clin. Immunol., 2011:127, 701-21. Erratum in J. Allergy Clin. Immunol., 2011:128, 739.

[4] Gołąb J., Jakóbisiak M., Lasek W. et al.: Immunologia. PZWL, 2012.

[5] Dinarello C.A.: A clinical perspective of IL-1 $\beta$ as the gatekeeper of inflammation. Eur. J. Immunol., 2011:41, 1203-1217.

[6] Corcos M., Guilbaud 0., Chaouat G. et al.: Cytokines and Anorexia Nervosa. Psychosom. Med., 2001:63, 502-504.

[7] Maedler K., Dharmadhikari G., Schumann D.M. et al.: Interleukin- targeted therapy for metabolic syndrome and type 2 diabetes. Handb. Exp. Pharmacol., 2011:203, 257-278.

[8] Nagata T., Tobitani W., Kiriike N. et al.: Capacity to produce cytokines during weight restoration in patients with anorexia nervosa. Psychosom. Med., 1999:61, 371-377.

[9] Schattner A., Tepper R., Steinbock M. et al.: Cytokines in anorexia nervosa-nutritional or neuroimmunal changes? Harefuah., 1992: $123,245-247$.

[10] Schattner A., Tepper R., Steinbock M. et al.: TNF, interferon-gamma and cell-mediated cytotoxicity in anorexia nervosa; effect of refeeding. J. Clin. Lab. Immunol., 1990:32, 183-184.

[11] Polack E., Nahmod V.E., Emeric-Sauval E. et al.: Low lymphocyte interferon-gamma production and variable proliferative response in anorexia nervosa patients. J. Clin. Immunol., 1993:13, 445-451.

[12] Vaisman N., Barak Y., Hahn T. et al.: Defective in vitro granulopoiesis in patients with anorexia nervosa. Pediatr. Res., 1996:40, 108111.

[13] Licinio J., Altemus M.E., Wong M. et al.: Circulating levels of interleukin-2 in patients with anorexia nervosa. Biol. Psychiatry, 1991: $29,56 \mathrm{~A}$.

[14] Vaisman N., Hahn T.: Tumor necrosis factor-alpha and anorexia: cause or effect? Metabolism, 1991:40, 720-723.

[15] Kahl K.G., Kruse N., Rieckmann P. et al.: Cytokine mRNA expression patterns in the disease course of female adolescents with anorexia nervosa. Psychoneuroendocrinology, 2004:29, 13-20.

[16] Gordon C.M., Goodman E., Emans S.J. et al.: Physiologic regulators of bone turnover in young women with anorexia nervosa. J. Pediatr., 2002:141, 64-70.

[17] Shimizu T., Satoh Y., Kaneko N. et al.: Factors involved in the regulation of plasma leptin levels in children and adolescents with anorexia nervosa. Pediatr. Int., 2005:47, 154-158.

[18] Raymond N.C., Dysken M., Bettin K. et al.: Cytokine production in patients with anorexia nervosa, bulimia nervosa, and obesity Int. J. Eat Disord., 2000:28, 293-302.

[19] American Psychiatric Association, Diagnostic and Statistical Manual of Mental Disorder (DSM IV) APA. Washington D.C. 1994.

[20] Palczewska l., Niedźwiecka Z.: Wskaźniki rozwoju somatycznego dzieci i młodzieży warszawskiej. Med. Wieku RozW., 2002:2, suppl I do $\mathrm{nr} 2$.

[21] Lewitt A., Brzęczek K., Krupienicz A.: Interwencje żywieniowe w leczeniu anoreksji - wskazówki dietetyczne. Endokrynol. Otył. Zab. Przem. Mat., 2008:4, 128-136.

[22] Brambilla F., Monti D., Franceschi C.: Plasma concentrations of interleukin-1-beta, interleukin-6 and tumor necrosis factor-alpha, and of their soluble receptors and receptor antagonist in anorexia nervosa. Psychiatry Res., 2001:103, 107-114.

[23] Corcos M., Guilbaud 0., Paterniti S. et al.: Involvement of cytokines in eating disorders: a critical review of the human literature. Psychoneuroendocrinology, 2003:28, 229-249.

[24] Licinio J., Litsvak S., Altemus M.E. et al.: Serum and CSF interleukin in bulimia nervosa. Biol. Psychiatry, 1990:27, 147.

[25] Allende L.M., Corell A., Manzanares J. et al.: Immunodeficiency associated with anorexia nervosa is secondary and improves after refeeding. Immunology, 1998:94 (4), 543-551.

[26] Nova E., Samartín S., Gómez S. et al.: The adaptive response of the immune system to the particular malnutrition of eating disorders. Eur. J. Clin. Nutr., 2002:56, S34-37.

[27] Nakai Y., Hamagaki S., Takagi R. et al.: Plasma concentrations of tumor necrosis factor-alpha (TNF-alpha) and soluble TNF receptors in patients with anorexia nervosa. J. Clin. Endocrinol. Metab., 1999:84, 1226-1228.

[28] Limone P., Biglino A., Bottino F. et al.: Evidence for a positive correlation between serum cortisol levels and IL-1beta production by peripheral mononuclear cells in anorexia nervosa. J. Endocrinol. Invest., 2000:23, 422-427.

[29] Brambilla F., Bellodi L., Brunetta M, et al.: Plasma concentrations of interleukin-1 beta, interleukin-6 and tumor necrosis factor-alpha in anorexia and bulimianervosa. Psychoneuroendocrinology, 1998:23, 439-447.

[30] Pomeroy C., Eckert E., Hu S. et al.: Role of interleukin-6 and transforming growth factor-beta in anorexia nervosa. Biol. Psychiatry, 1994:36, 836-839.

[31] Mitchell J.E., Eckert E., Pomeroy C.: The role of cytokine in anorexia nervosa. Neuropsychopharmacology, 1994:10, $206 \mathrm{~S}$. 
[32] Bessler H., Karp L., Notti I.: Cytokine production in anorexia nervosa. Clin. Neuropharmacol., 1993:16, 237-243.

[33] Monteleone P., Maes M., Fabrazzo M. et al.: Immunoendocrine findings in patients with eating disorders. Neuropsychobiology, 1999: 40, $115-120$.

[34] Plata-Salamán C.R., Sonti G., Borkoski J.P. et al.: Anorexia induced by chronic central administration of cytokines at estimated pathophysiological concentrations. Physiol. Behav., 1996:60, 867-875.

[35] Konsman J.P., Dantzer R.: How the immune and nervous systems interact during disease-associated anorexia. Nutrition, 2001:17, 664-668.

[36] Dunn A.J., Wang T.: Effects of cytokines on brain catecholamines and indolamines. Biol. Psychiatry, 1997:42.

[37] Bessler H., Karp L., Notti l.: Cytokine production in anorexia nervosa. Clin. Neuropharmacol., 1993:16, 237-243.

[38] Sävendahl L., Underwood L.E.: Decreased interleukin-2 production from cultured peripheral blood mononuclear cells in human acute starvation. J. Clin. Endocrinol. Metab., 1997:82, 1177-1180.

[39] Nagata T., Kiriike N., Tobitani W. et al.: Lymphocyte subset, lymphocyte proliferative response, and soluble interleukin-2 receptor in anorexic patients. Biol. Psychiatry, 1999:45, 471-474.

[40] Ziora K., Oświęcimska J., Świętochowska E. et al.: Analiza zależności pomiędzy stężeniem wybranych hormonów tkanki ttuszczowej (adiponektyny i leptyny) a stężeniem hormonów tarczycy, nadnerczy i gonad w surowicy u dziewcząt z jadłowstrętem psychicznym. Endokr. Ped., 2010:9, 9-22.

[41] Ziora K., Oświęcimska J., Świętochowska E. et al.: Assesment of serum levels resistin in girls with anorexia nervosa. Neuroendocrinol. Lett., 2011:32, 101-106. 